\title{
Inverted hypopyon in the eye
}

\author{
Koushik Tripathy, Yog Raj Sharma
}

Dr Rajendra Prasad Centre for Ophthalmic Sciences, All India Institute of Medical Sciences, New Delhi, India

\section{Correspondence to}

Dr Koushik Tripathy,

koushiktripathy@gmail.com

Accepted 3 February 2016
CrossMark

\section{To cite: Tripathy $\mathrm{K}$,}

Sharma YR. BMJ Case Rep

Published online: [please

include Day Month Year]

doi:10.1136/bcr-2016-

214638

\section{DESCRIPTION}

A 33-year-old woman presented with pain in the left eye. She had a history of wearing glasses of high minus power $(-11 \mathrm{D})$ in both eyes. She had undergone vitreoretinal surgery with silicone oil (SO) tamponade for retinal breaks as management of rhegmatogenous retinal detachment (RRD) in the left eye 2 years prior. There was aphakia, inferior peripheral iridectomy (PI), emulsified $\mathrm{SO}$ in the anterior chamber accumulating superiorly with a horizontal oil-aqueous level (hyperoleon, figure 1), increased intraocular pressure (IOP) and glaucomatous optic neuropathy.

Hyperoleon is seen superiorly in the anterior chamber as SO (specific gravity 0.97 ) is lighter than aqueous humour. On the contrary, hypopyon and hyphaema are manifestations of deposition of pus and haemorrhage, respectively, in the inferior part of the anterior chamber. Hypopyon denotes an inflammatory or infective process and should not be confused with a hyperoleon. Hyperoleon is a

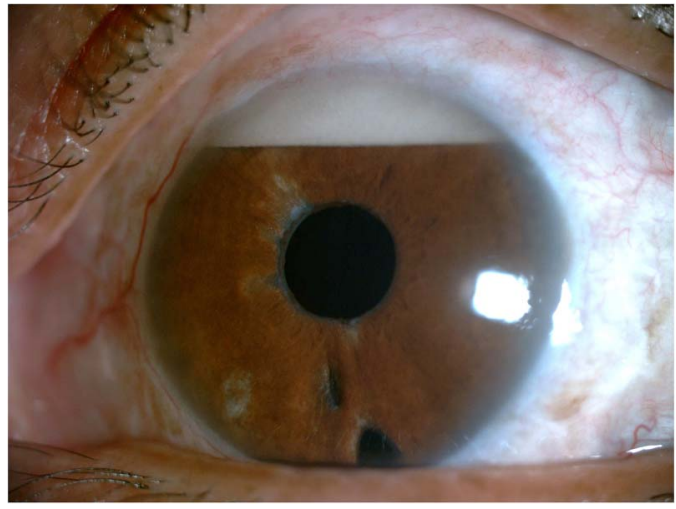

Figure 1 Slit lamp photograph of the left eye showing a white lesion in the superior part of the anterior chamber with a horizontal level suggestive of a hyperoleon. manifestation of emulsification of SO and is commonly associated with glaucoma. Inferior PI (Ando's PI) ${ }^{1}$ is performed in the SO-filled eye to prevent pupillary block glaucoma. Hyperoleon necessitates SO removal.

\section{Learning points}

- Hyperoleon is a complication of intraocular injection of silicone oil that is used for the management of retinal detachment.

- In contrast to hyphaema and hypopyon, which are seen in the inferior part of the anterior chamber, hyperoleon is seen superiorly as silicone oil is lighter than aqueous humour.

- Hyperoleon signifies silicone oil emulsification and is usually associated with glaucoma.

- Hyperoleon is an indication for silicone oil removal.

Contributors KT and YRS had full access to all of the data in the study, and take responsibility for the integrity of the data and the accuracy of the data analysis. KT and YRS were responsible for study concept and design., and analysis and interpretation of the data. KT was responsible for acquisition of the data. All the authors drafted the manuscript; responsible for critical revision of the manuscript for important intellectual content, and also for study supervision.

Competing interests None declared.

Patient consent Obtained.

Provenance and peer review Not commissioned; externally pee reviewed.

\section{REFERENCE}

1 Beekhuis WH, Ando F, Zivojnović R, et al. Basal iridectomy at 6 $o^{\prime}$ clock in the aphakic eye treated with silicone oil: prevention of keratopathy and secondary glaucoma. $\mathrm{Br} J$ Ophthalmol 1987;71:197-200.

Copyright 2016 BMJ Publishing Group. All rights reserved. For permission to reuse any of this content visit http://group.bmj.com/group/rights-licensing/permissions.

BMJ Case Report Fellows may re-use this article for personal use and teaching without any further permission.

Become a Fellow of BMJ Case Reports today and you can:

- Submit as many cases as you like

- Enjoy fast sympathetic peer review and rapid publication of accepted articles

- Access all the published articles

- Re-use any of the published material for personal use and teaching without further permission

For information on Institutional Fellowships contact consortiasales@bmjgroup.com

Visit casereports.bmj.com for more articles like this and to become a Fellow 